Hydraulic Engineering Repository

Ein Service der Bundesanstalt für Wasserbau

Shwiyhat, Nathan; Xiao, Ming

Effect of Suffusion on Mechanical Characteristics of Sand

Verfügbar unter / Available at:

https://hdl.handle.net/20.500.11970/100308

Vorgeschlagene Zitierweise / Suggested citation:

Shwiyhat, Nathan; Xiao, Ming (2010): Effect of Suffusion on Mechanical Characteristics of Sand. In: Burns, Susan E.; Bhatia, Shobha K.; Avila, Catherine M. C.; Hunt, Beatrice E. (Hg.): Proceedings 5th International Conference on Scour and Erosion (ICSE-5), November 7-10, 2010, San Francisco, USA. Reston, Va.:

American Society of Civil Engineers. S. 378-386. 


\title{
Effect of Suffusion on Mechanical Characteristics of Sand
}

\author{
Nathan Shwiyhat, P.E. ${ }^{1}$ and Ming Xiao, Ph.D., P.E. ${ }^{2}$ \\ ${ }^{1}$ Project Engineer of BSK Associates and Graduate Student at California State \\ University, Fresno, CA., USA. Email: nshwiyhat@bskinc.com. \\ ${ }^{2}$ Assistant Professor, Department of Civil and Geomatics Engineering, California \\ State University, Fresno, CA., USA. Email: mxiao@csufresno.edu. Phone: (559) \\ 278-7588.
}

\begin{abstract}
The mechanical characteristics of earth dams and levees, such as settlement, permeability, and strength, can be affected by internal erosion in the forms of piping and suffusion. This paper reports a preliminary experimental study on the changing mechanical characteristics (permeability, consolidation) with the progression of suffusion of a sandy soil. The internal erosion tests are conducted using a triaxial apparatus. The pedestal of the triaxial cell is modified to allow seepage and eroded soil particles to exit the specimen into an effluent tank. The seepage is induced in the specimen by controlled constant hydraulic gradient. The eroded soils are collected in the effluent tank so that the erosion rate and extent can be measured. Variations of the specimen's permeability and volume during the erosion are recorded. With approximately $5.5 \%$ fines in the sand, the test suggests that suffusion can occur and cause soil settlement. Suffusion of finer particles may also clog the downstream soil layer and results in permeability reduction. Suffusion and volume reduction gradually diminish relatively quickly to an un-measurable level after $4 \mathrm{hr}$ of seepage through the soil under a hydraulic gradient of approximately 20 .
\end{abstract}

\section{INTRODUCTION}

Internal erosion can have devastating consequences to earthen, hydraulic structures. A survey of 11,192 dams revealed that 136 dams showed signs of damage and $46 \%$ of those damaged were related to internal erosion (Foster et al., 2000). During Hurricane Katrina, three levee breaches were possibly caused by underseepageinduced failure due to piping (Seed et al., 2008a, 2008b; Sills et al, 2008). Internal erosion can be divided into two main forms: piping and suffusion (if neglecting dispersion). Piping is a process of soil particles being mobilized and then transported downstream along a flow path by flowing water. The eroded soils result in a tubular pipe that progresses upstream in the soil matrix. The erosion could lead to the sudden collapse of the structure and consequently massive flooding and devastation in the downstream.

The other form of internal erosion is suffusion, which is the migration of fine soil particles within a coarser soil matrix, or soil skeleton. Suffusion usually occurs in soil matrices that are sufficiently coarse to permit the movement of fines in the 
constrictions formed between particle contact points. Wan and Fell (2008) reported that more porous soil structures allow more readily for suffusion. Additionally, they found that soils with plastic fines require larger hydraulic gradients for erosion to occur. The fines susceptible to transport are those entirely contained within the pores of the coarser structure and may not support effective stress, as the coarse structure carries external loads. In order for the coarse structure to behave as a load-supporting skeleton, the fine particles must be scarce enough in quantity so they do not fill the voids entirely within the coarse skeleton (Wan and Fell, 2008). Suffusion, though less catastrophic in terms of potential failure mechanisms, can be chronically destructive. Suffusion commonly results in the clogging of soil filters or drainage layers and lead to the presence of excess pore water pressure. Suffusion may also result in increased porosity, permeability, seepage, and accentuated consolidation of a soil layer or earthen structure. Experimental research by Wan and Fell (2004) found that "...50\% of the finer fraction as defined by the point of inflection of broadly graded soils and the fine limit of the gap in gap-graded soils can be eroded" by suffusion in internally unstable soils. Suffusion and the subsequent void ratio increase could cause settlement. More research has been focused on when, where, and why internal erosion can occur but less on the lasting mechanical effects of internal erosion, particularly the effect of suffusion on the settlement potential of a soil stratum due to the loss of fine particles within the soil skeleton.

To model the in-situ stress conditions, triaxial tests can be used to study suffusion and piping. Sanchez et al. (1983) were the first researches to evaluate the erosion potential of embankment core materials using triaxial erosion tests. The recent experiments by Bendahmane et al. (2008) revealed the complex effects of confining pressure on suffusion. The true triaxial tests by Richards and Reddy (2008) preliminarily indicated the confining stress and pore pressure are critical to piping initiation. This research employs the similar experimental design of triaxial erosion tests and focuses on the effect of suffusion on the mechanical behaviors of a sandy soil.

\section{MATERIALS AND METHODOLOGY}

A poorly-graded sandy soil is tested. The sand was obtained from a local aggregate mining company operating on the San Joaquin River in Fresno, California. Kaolinite was added to, and evenly mixed in the sand at a ratio of $2.5 \%$ (by dry mass), so that the fine particles may be subjected to suffusion. The gradation is presented on Figure 1. The total fine content (passing U.S. \#200 sieve) in the mixed soil is approximately $5.5 \%$. Modified proctor test (ASTM D-1557) performed on the mixed sample found a maximum dry density of $1.867 \mathrm{~g} / \mathrm{cm}^{3}$ (or $116.5 \mathrm{lb} / \mathrm{ft}^{3}$ ) at an optimum moisture content of $9.5 \%$. Additional information pertaining to the river sand and the Kaolinite clay used in this experiment is contained in Table 1. 


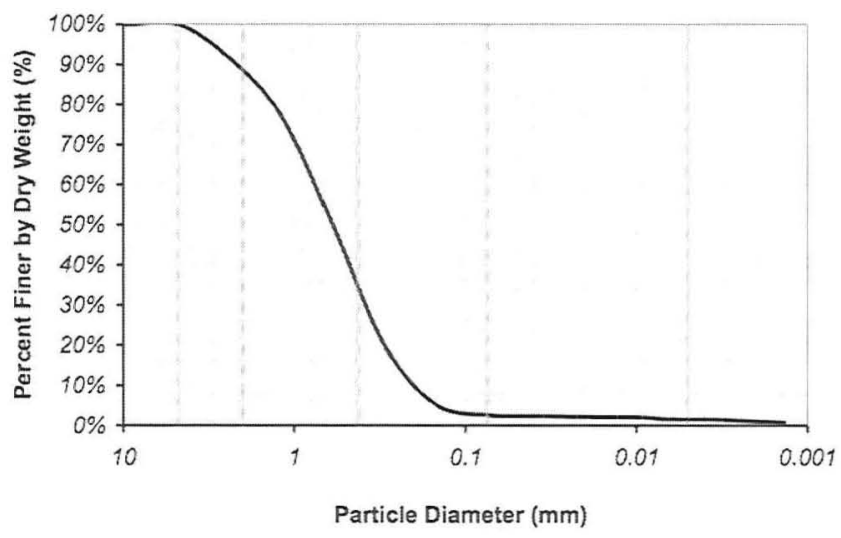

Figure 1 - Grain size distribution of the sandy soil with $2.5 \%$ Kaolinite

Table 1 - Soil properties

\begin{tabular}{c|c|c}
\hline Soil Gradation & $\begin{array}{c}\text { Poorly Graded } \\
\text { Sand (SP) }\end{array}$ & $\begin{array}{c}\text { Kaolim } \\
\text { (CL) }\end{array}$ \\
\hline \% Coarse Sand Fraction & 12 & -- \\
\hline \% Medium Sand Fraction & 55 & -- \\
\hline \% Fine Sand Fraction & 30 & -- \\
\hline \% Silt & 1 & 24 \\
\hline \% Clay (Clay Sized) & 2 & 76 \\
\hline $\mathrm{D}_{10}(\mathrm{~mm})$ & 0.21 & -- \\
\hline $\mathrm{D}_{30}(\mathrm{~mm})$ & 0.39 & -- \\
\hline $\mathrm{D}_{60}(\mathrm{~mm})$ & 0.77 & -- \\
\hline Coefficient of Uniformity, $\mathrm{C}_{\mathrm{u}}$ & 3.7 & -- \\
\hline Coefficient of Gradation, $\mathrm{C}_{\mathfrak{c}}$ & 0.94 & -- \\
\hline Specific Gravity & 2.69 & 2.61 \\
\hline
\end{tabular}

The suffusion tests are conducted using a triaxial apparatus, which is modified to allow effluent water and eroded soil particles to exit the cell and be captured in an effluent tank. The effluent tank can be pressurized to simulate any reasonable downstream pressure. For this test the downstream pressure was maintained at atmospheric pressure. During the suffusion process, the change in total specimen volume is monitored by a Volume Change Transducer Unit (VCU) connected to the cell water supply. Figure 2 provides a photo diagram of the test setup and Figure 3 illustrates the details of the modifications to the triaxial cell base pedestal. The base pedestal is connected to the bottom of the triaxial cell and then to a large control valve that is located on the bottom of the base, outside of the cell. The top portion of 


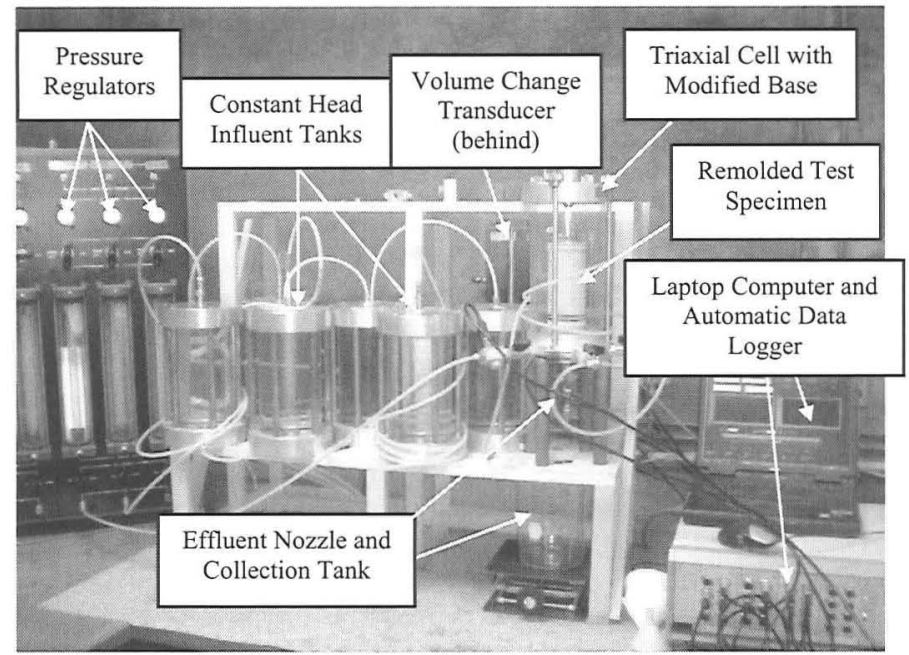

Figure 2 - Photo diagram of test setup

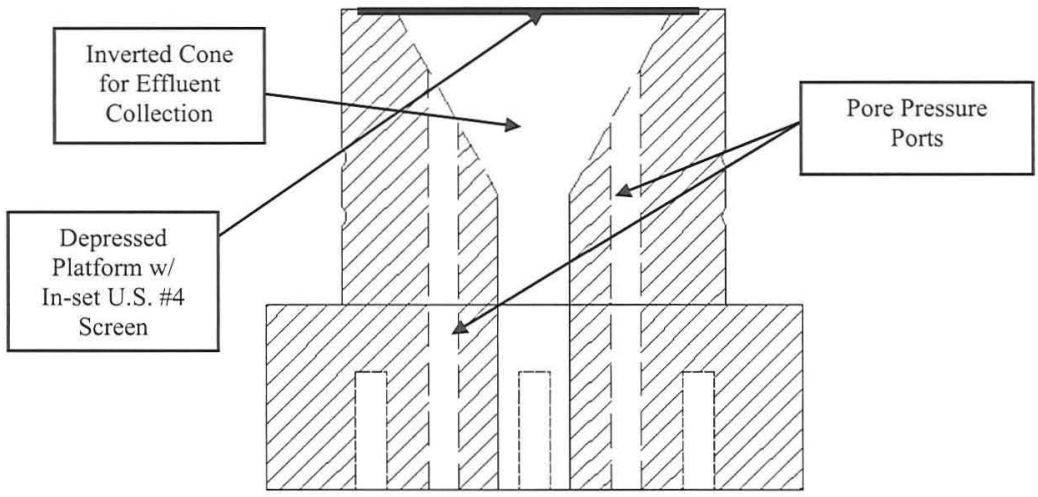

Figure 3 - Details of modifications to triaxial base pedestal

the pedestal is bored out in the shape of an inverted cone and funnels into a large port that connects to the control valve. A U.S. \#4 screen $(4.75 \mathrm{~mm})$ is set into a depressed platform on the top of the pedestal to support the remolded specimen while permitting unrestricted drainage. The screen is intended to support the specimen during the undrained compression test that follows the internal erosion test to examine the strength reduction due to suffusion. Due to the page limit of this paper, compression test results are not reported. 
A specimen of $5.11 \mathrm{~cm}$ (or 2 inch) in diameter and $10.22 \mathrm{~cm}$ (or 4 inch) in height is remolded to $85 \%$ of the maximum dry density at the optimum moisture content. The specimen is saturated with de-aired, deionized water under pressure applied through a pneumatic bladder that pressurizes the de-aired water. The specimen is maintained at an effective stress of $13.8 \mathrm{kN} / \mathrm{m}^{2}$ (or 2 psi) during the saturation process until a minimum " $\mathrm{B}$ " value of 0.95 is obtained. Bendahmane et al. (2008) found that for clay-sand mixtures, there first exists a critical gradient at which suffusion of the fine clay particles occurs and as the gradient is increased, there also exists a second critical gradient at which the sand structure is eroded by piping (backward erosion). Our previous tests found that at the critical gradient for piping, the sandy specimen typically collapsed upon the initiation of piping. The goal of this research sets out to quantify the sustained mechanical changes in soil due to suffusion, so the testing is carried out at a gradient less than that required for the initiation of piping of the sand matrix. After saturation is reached, the specimen is subjected to a constant downward hydraulic gradient of approximately 20.8. The effluent is continuously collected during the erosion process at predetermined volume intervals. The total volume change of the specimen is continuously monitored via the VCU. Permeability of the specimen is frequently measured with the collected effluent volume. The erosion is continued until the effluent water visually clears up. From each collected effluent with eroded soils, the volume of effluent is recorded and then the entire contents are oven dried and weighed to determine the mass of the eroded material to the nearest one-thousandth of a gram.

\section{RESULTS AND DISCUSSION}

The permeability, erosion behavior, and volumetric behavior of the specimen are monitored during the entire erosion test, which runs for $250 \mathrm{~min}$. The results are provided in the following sections.

\section{Permeability Behavior}

During the erosion test, the permeability of the specimen generally decreased as the suffusion continued (Figure 4). Approximately one order of magnitude in permeability reduction was observed. Several other researchers have reported similar permeability reductions in the presence of suffusion. The permeability reduction is due to the clogging of constrictions between soil solids by eroded fines. The decreased diameters of the pore throats result in a decreased porosity (perhaps across only a thin and limiting layer at the bottom of the specimen), reducing the overall permeability of the entire specimen. 


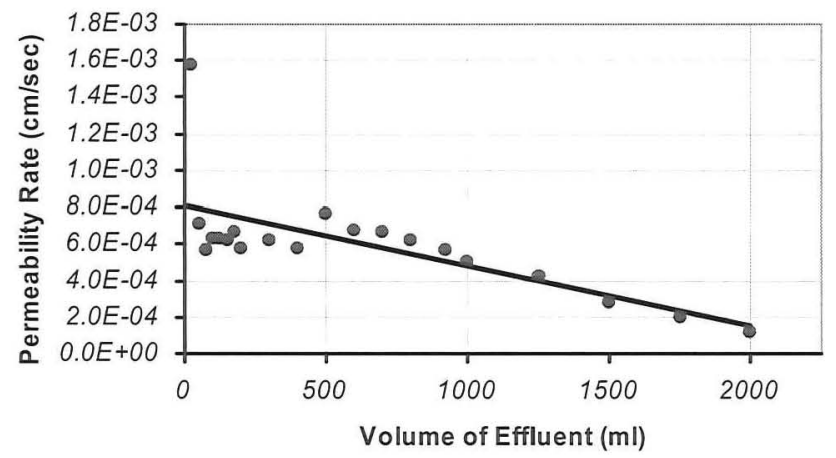

Figure 4 - Permeability variation with effluent volume

\section{Suffusion Behavior}

The suffusion rate also decreased as the test progressed. In total, 1.510 gram of soil solids were eroded during the testing. This is approximately $0.5 \%$ of the dry mass of the specimen. Figure 5 shows the total mass of eroded soils with respect to time and Figure 6 shows the concentration of the eroded solids in the effluent with respect to the total volume of effluent. Since the fine solids that are contained loosely within the pore structure of the coarse skeleton are more susceptible to suffusion, an asymptotic trend (shown in Figure 5) is expected — as the fines are gradually washed out, the coarse skeleton remains. Additionally, with decreasing size of pore throat constrictions due to the likely particle clogging at the downstream section of the specimen, suffusion gradually diminishes until no solids are washed out, as indicated in both Figures 5 and 6 .

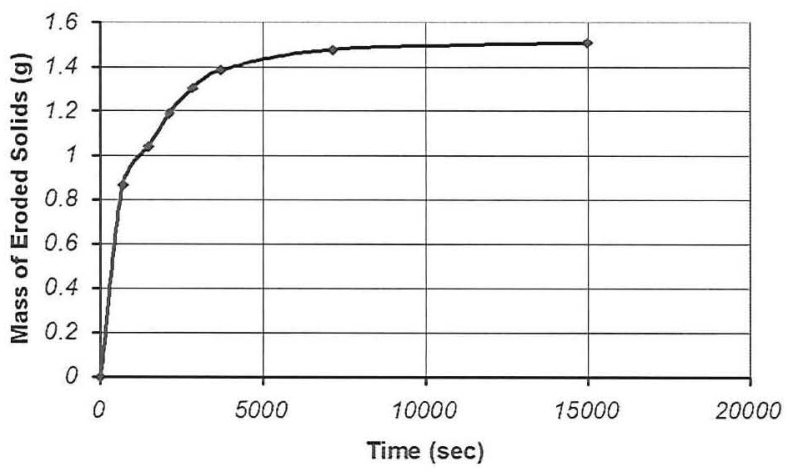

Figure 5 - Eroded mass versus time 


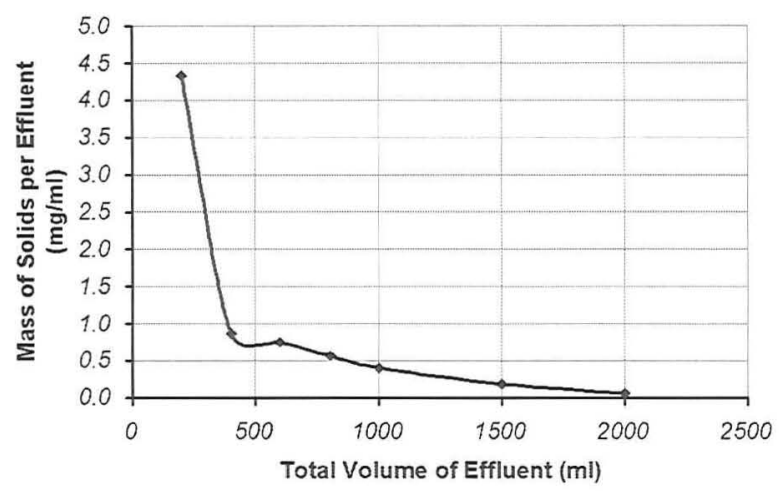

Figure 6 - Concentration of soil solids in effluent versus total effluent volume

\section{Volumetric Behavior}

As internal erosion occurs, the specimen volume decreases. Figures 7 and 8 show the total specimen volume reduction (in percentage of initial total specimen volume) with time and effluent volume, respectively. Also presented in both figures are the calculated specimen volume, which is based on the volume of the eroded particles and the pore volume that the eroded particles may construct. In the calculated volume prediction, it is assumed that the void ratio of the eroded fines (when they construct pores) is the same as the average void ratio of the entire specimen. Figures 7 and 8 both suggest that the extent of volume reduction appears to be minor, which is comparable to the degree of suffusion that occurred in the experiment - this test suffered only approximately $0.3 \%$ volume reduction due to an approximately $0.5 \%$ eroded soil mass. The results show that the volume change stabilizes in the early stage of the test while the suffusion continued throughout the test. It could be because loose and unsupported large particles near the base of the specimen eroded first, causing relatively large reduction in volume at the beginning of the test. After that, suffusion of finer particles did not cause measurable volume change. It is also learned from this exploratory tests that volume change due to suffusion may also depends on percentage of fine contents. Apparently 5.5\% fines (< $0.075 \mathrm{~mm}$ ) in the specimen caused little volume reduction as a result of the fines suffusion. Our ongoing experiments using the same methodology employ a smaller screen (U.S. \#10 sieve, instead of \#4 sieve) at the bottom. The new tests showed the volume reduction trend becomes shallower and volume reduction parallels the suffusion throughout the test (Shwiyhat, 2010). The results found a similar volume reduction $(0.26 \%)$ with only $0.15 \%$ decrease in sample mass. 


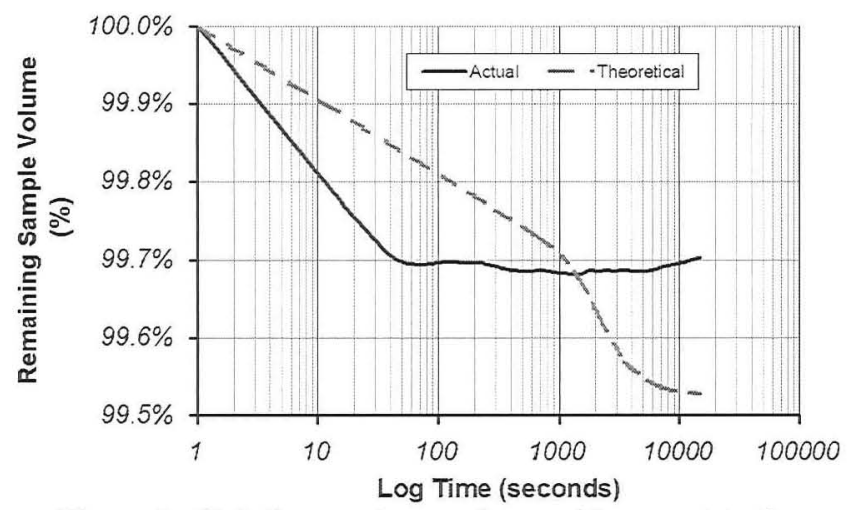

Figure 7 - Relative specimen volume with respect to time

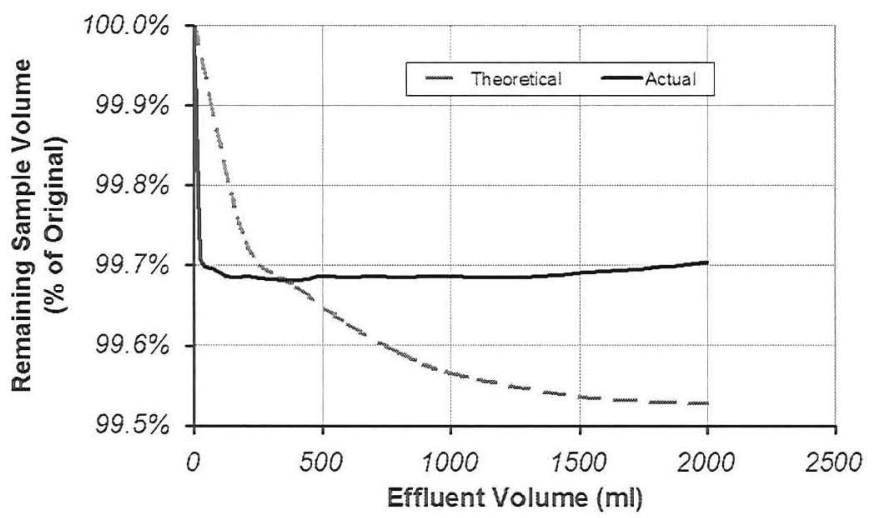

Figure 8 - Relative specimen volume with respect to total effluent volume

\section{CONCLUSIONS}

This paper presents the findings of a preliminary experimental investigation on the mechanical behaviors of a sandy soil that is subjected to suffusion. With approximately $5.5 \%$ fines in the sand, the test suggests that suffusion can occur and cause soil settlement. Suffusion of fine particles may also clog the downstream soil layer and results in permeability reduction. In this experiment, suffusion and volume reduction gradually diminish relatively quickly to an un-measurable level after 4 hours of seepage through the soil under a hydraulic gradient of approximately 20 . A systematic experimental program by the authors, following the same methodology presented in this paper, continues to verify the preliminary findings through testing of poorly graded and gap-graded soils with various fine contents. 


\section{ACKNOWLEDGEMENT}

The authors thank the support of this research by California State University, Fresno.

\section{REFERENCES}

Bendahmane, F., Marot, D., Alexis, A. (2008). "Experimental Parametric Study of Suffusion and Backward Erosion." Journal of Geotechnical and Geoenvironmental Engineering, 134 (1): 57-67

Foster, M., Fell, R., and Spannagle, M. (2000). "The Statistics of Embankment Dam Failures and Accidents." Canadian Geotechnical Journal, 37(5): 1000-1024.

Richards, K.S., and Reddy, K.R. (2008). "Experimental investigation of piping potential in earthen structures." Geosustainability and Geohazard Mitigation, Proceedings of GeoCongress 2008, ASCE Geotechnical Special Publication No. 178, 367-376. Reddy et al. (Ed). ASCE Geo-Institute.

Sanchez, R.L., Strutynsky, A.I., and Silver, M.L. (1983). "Evaluation of the erosion potential of embankment core materials using the laboratory triaxial erosion test procedure." Tech. Rep. GL-83-4, Army Engineer Waterways Experiment Station, Vicksburg, MS, Geotechnical Lab, Apr 1983.

Seed, R. B., Bea, R.G., Abdelmalak, R. I., Athanasopoulos-Zekkos, A., Boutwell, G.P., Bray, J.D., Cheung, C., Cobos-Roa D., Ehrensing, L., Harder Jr., L.F., Pestana, J.M., Riemer, M.F., Rogers, J.D., Storesund, R., Vera-Grunauer, X, ; and Wartman, J. (2008a). "New Orleans and Hurricane Katrina. II: the central region and the lower Ninth Ward." ASCE J. of Geotechnical and Geoenvironmental Engineering, 134(5): 718-739.

Seed, R. B., Bea, R.G., Abdelmalak, R. I., Athanasopoulos-Zekkos, A., Boutwell, G.P., Bray, J.D., Cheung, C., Cobos-Roa D., Cohen-Waeber, J., Collins, B.D., Harder Jr., L.F, Kayen, R.E., Pestana, J.M., Riemer, M.F., Rogers, J.D., Storesund, R., Vera-Grunauer, X, ; and Wartman, J. (2008b). "New Orleans and Hurricane Katrina. IV: Orleans East Bank (Metro) Protected Basin." ASCE J. of Geotechnical and Geoenvironmental Engineering, 134(5): 762-779.

Shwiyhat, N. (2010). "Effect of Suffusion on Mechanical Characteristics of Sand." MS thesis, Department of Civil and Geomatics Engineering, California State University, Fresno, Dec 2010.

Sills, G.L., Vroman, N.D., Wahl, R.E., Schwanz, N.T. (2008). Overview of New Orleans levee failures: lessons learned and their impact on national levee design and assessment. ASCE Journal of Geotechnical and Geoenvironmental Engineering, 134(5): 556-565.

Wan, C. F., Fell, R. (2004). "Investigation of Rate of Erosion of Soils in Embankment Dams." Journal of Geotechnical and Geoenvironmental Engineering, 130 (4): 373-380.

Wan, C. F., Fell, R., (2008). "Assessing the Potential of Internal Instability and Suffusion in Embankment Dams and Their Foundations". Journal of Geotechnical and Geoenvironmental Engineering, 134 (3): 401-407. 